\title{
Existential and Possessive Constructions in English and German
}

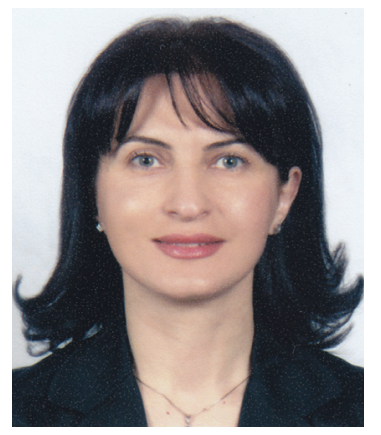

Siranush Khandanyan
$\mathrm{T}$ he present paper focuses on semantic and syntactic distinction among the various German counterparts of existential there and presents ways in which constructions with there can be taught more effectively to native speakers or learners of English. The study comes to prove that there is also a close relationship between existential expressions and possessive constructions containing haben or have in German and English.

A striking case of non-congruence between the sense relations of German and English concerns the ways in which the existence of a particular entity is communicated. For this purpose English frequently uses the presentative phrase there is.

There is a book on the table.

There are many animals in the zoo.

German has three expressions corresponding to the English introducer there is which are syntactically and semantically distinct. These expressions are: es gibt, da ist, es ist. The primary meaning of existential construction es gibt is found to be that of absolute existence. Unlike this construction, the two other constructions containing sein (es ist and $d a$ ist) express locative, implicitly non-permanent existence.

Current theories of communicative function show the ways in which German and English, despite their word order differences, achieve the communicative goals of the existential construction. Es gibt is equivalent to English there is or there are. It is followed by the accusative case (Moeller 1996:120). This is the explanation given for the meaning and usage of es gibt in a widely used textbook, Deutch Heute. This description appears to be standard; there are similar statements in various other textbooks currently in use for the teaching of German in the United States.

In English, existential ${ }^{1}$ sentences typically begin with the introducer there:

There are elephants in Africa.

There is a new school in this district.

This introductory there is often followed first by a form to be, then an indefinite noun phrase and a locative adverb.

The close relationship between existential expressions in German and English and possessive constructions with haben or have has been noted by various linguists. Lyons, for example, using evidence from English and Russian theorizes that the existential and possessive constructions of each language are actually derived from the same source - the locative (Lyons 1967). 
Clark and Freeze concur with Lyons that this sentence types are all locative in origin and are related in many languages. Clark illustrates this relationship using the sentences shown below:

1.There is a book on the table. (existential)

2.The book is on the table. (locative)

3.Tom has a book. (possessive)

4.The book is Tom's. (possessive)

Each of these constructions describes the location of an object, either in some physical space, as in (1) and (2), or in someone's possession, as in (3) and (4).

According to Freeze, in many languages the predication have and the existential share the same constituents in the same order (when the possessor is considered to be a locative element). For example, Quirk refers to existential sentences with have "asserting that the subject of have in these constructions denotes a person, thing, etc. indirectly involved in the existential proposition" (Quirk 1972:961).

The following sentence pairs show that this type of lexical relationship holds both in English and German:

1. a. There are a lot of restaurants in my town.

b. My home town has a lot of restaurants.

2. a. Es gibt viele Restaurants in meiner Heimatstadt.

b. Meine Heimatstadt hat viele Restaurants.

These sentence pairs show that there is a great deal of similarity between the two languages as far as their existential and have constructions are concerned. The sentence in 1.b can be reordered as a sentence with the unstressed there introducer and the sentence in $2 . \mathrm{b}$ can be reformulated as a construction beginning with es gibt.

Erdman points out that some existential constructions with there, like the sentence 3.a can never be replaced by a have construction (Erdman 1978):

\section{3. a. There is a stranger at the door.}

b. The door has a stranger (at it).

He attempts to divide the various types of have constructions in English into subgroups based on apparent syntactic differences, e.g. use or non-use of a locative (prepositional) phrase. He notes, for example, that some sentences do not include a locative phrase while others do, and that there are still other sentences in which the use of the locative phrase is optional. Here are a few sentences to illustrate this:

4. a. The ground has snow.

b. The ground has snow on it.

5. a. The mattress has a rent.

b. The mattress has a rent in it. 
The difference among the sentences 3, 4, and 5 actually reflects differences in their semantics, and the use (or non-use) of a locative phrase in have constructions in English follows a predictable set of rules, and besides, the restrictions on the use of a locative phrase in German have constructions are more complex than those in English.

As it has already been stated, the German expression es gibt is used to indicate permanent existence. Sentences containing es gibt which also contain a locative phrase can frequently be transformed into have construction:

6. a. Es gibt viele Klassenzimmer in der Schule.

(There are many classrooms in the school.)

b. Die Schule hat viele Klassenzimmer.

(The school has many classrooms).

7. a. Es gibt viele Lowen in Africa.

(There are many lions in Africa)

b. Africa hat viele Lowen.

(Africa has many lions).

8. a. Es gibt einen Brunnen im Garten.

(There is a fountain in the garden).

b. Der Garten hat einen Brunnen.

(The garden has a fountain).

The have construction in English is used for both permanent and temporary conditions. For example, when the condition in the have construction is temporary, this is indicated by the addition of a prepositional phrase that includes an anaphor for the locationpossessor denoted by the subject:

9. a. There is mud on her dress.

b. Her dress has mud.

c. Her dress has mud on it.

Her dress has mud on it is a temporary and not a permanent condition; it therefore requires the inclusion of the locative expression on it.

While describing have constructions showing permanent condition, it is possible to come across a prepositional phrase:

\section{The library has a lot of books (in it).}

It is apparent that both variants (with and without the locative phrase) are acceptable.

Kirkwood overlooks important differences between the ways in which possessive have constructions behave in English and German. He provides two sample sentences in German which include a prepositional phrase and which are, therefore, both stylistically unacceptable (Kirkwood 1969:35): 


\section{Der Stuhl hat ein Schild dran.}

The chair has a sign on it.

12. Die Flasche hat noch Wein drin.

The bottle still has wine in it.

Kirkwood notices that this pattern (with a prepositional phrase) "has less wide distribution in German than its English counterpart has in English" and, therefore "is just barely acceptable". On the other hand, the following have constructions are considered to be acceptable (Kirkwood 1969):

\section{3. a. Ich habe ein Glas vor mir. \\ I have a glass before me. \\ b. Es gibt ein Glas vor mir. \\ 14. a. Sie hat ein Buch vor sich. \\ She has a book before herself. \\ b. Es gibt ein Buch vor ihr.}

Like their English counterparts, these constructions can be used to describe a situation that is temporary. And as a result the sentences 13.b and 14.b cannot be reformulated as existential constructions es gibt. In German, if the subject in the possessive haben construction is -animate then the possessive haben construction, like constructions containing es gibt, expresses permanence. This possessive haben construction does not permit the inclusion of an anaphoric locative prepositional phrase. If the German possessive haben construction has a +animate subject instead, it may contain a prepositional phrase (which includes an anaphoric dative pronoun. Unlike constructions having a -animate subject, these possessive haben constructions do not connote permanence and can, therefore, not be reformulated as a construction beginning with es gibt.

In English possessive have constructions may express either permanence or impermanence, regardless of whether they have an animate or a non -animate subject. When impermanence is expressed, they require the inclusion of a locative prepositional phrase, which includes an anaphor for the subject. Constructions expressing permanence may also include a locative prepositional phrase. Finally, the reformulation of a there sentence as a have construction is possible only when the preposition appearing in the locative phrase expresses concrete spatial relations.

Hence, the study has shown that although there is a close relationship between English and German existential and possessive have constructions, these constructions are subject to different restrictions in each of these languages.

\section{Notes:}

1. Sentences which express the existence of a person or entity - often in a particular location - are known as existential. The term "existential" is introduced by Jespersen in his Philosophy of Grammar to refer to sentences "corresponding to English sen- 
tences with there is or there are, in which the existence of something is asserted or denied" (Jespersen 1924:155).

\section{References:}

1. Breivik, L. (1977) A Note on the Genesis of Existential "there". // English Studies 58. Issue 4.

2. Clark, Ev. (1970) Locationals: a Study of the Relations between "existential", "locative", and "possessive" Constructions. // Working Papers on Language Universals. Language Universals Project. Stanford: Stanford University Press.

3. Erdman, P. (1978) "There" Constructions in English and German. IRAL, 16.3.

4. Freeze, R. (1992) Existentials and other Locatives. // Language, 68-3. Linguistic Society of America.

5. Hawkins, J.A. (1986) A Comparative Typology of English and German. Texas: Routledge and University of Texas Press.

6. Jespersen, O. (1948) A Modern English Grammar on Historical Principles: Part III Syntax. Northampton: John Dickens and Co. Ltd.

7. Keith, A. (1971) A Note on the Source of "there is" Existential Sentences. // Foundations of Language 17. Beijing: World Publishing Corporation.

8. Kirkwood, H. (1969) Remarks on Existential-locative and Possessive-locative Sentences in English and German. // Philologica Pragensia 4.

9. Lyons, J. (1967) A Note on Possessive, Existential, and Locative Sentences. // Foundations of Language 3. Beijing: World Publishing Corporation.

10. Moeller, J. and others (1996) Deutch Heute. Grundstufe Sixth edition. Boston: Houghton Mifflin Co.

11. Quirk, R. (1951) Explitive or Existential "there”. London: Medieval Studies 2.

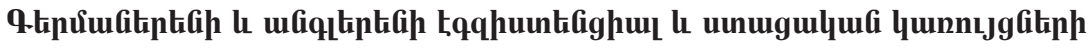 unpuhupuptpnıpjnılip}

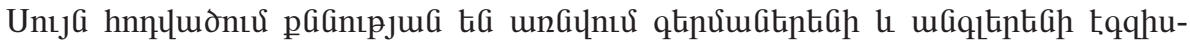
untighul (es gibt / there is) lo unugulqui (have / haben) lunnıggitiph hưuunupu-

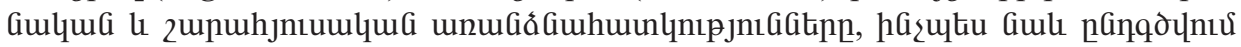

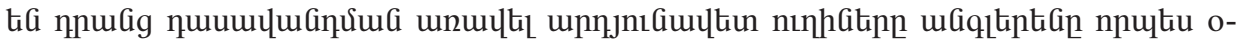

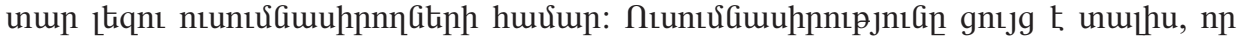

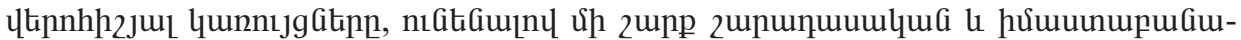

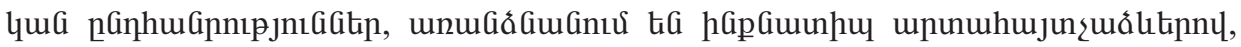

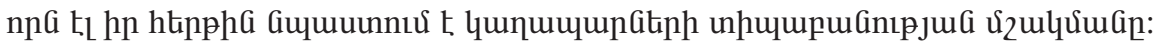

